\title{
Resection of Giant Liver Metastasis of Gastrointestinal Stromal Tumor Using Intraoperative Ultrasound Guidance
}

\author{
Alin Kraft ${ }^{1,2}$, Alexandru Bârcu ${ }^{1,2}$, Adina Croitoru ${ }^{3,6}$, Ioana Lupescu ${ }^{4,7}$, Dana Tomescu ${ }^{5,7}$, Irinel Popescu ${ }^{2,6}$, \\ Florin Botea ${ }^{2,6^{*}}$ \\ 'Doctoral School in Medicine, "Titu Maiorescu" University, Bucharest, Romania \\ ${ }^{2}$ Center of General Surgery and Liver Transplantation, Fundeni Clinical Institute, Bucharest, Romania \\ ${ }^{3}$ Department of Oncology, "Fundeni" Clinical Institute, Bucharest, Romania \\ ${ }^{4}$ Department of Radiology and Imaging, "Fundeni" Clinical Institute, Bucharest, Romania \\ ${ }^{5}$ Department of Intensive Care and Anesthesiology, "Fundeni” Clinical Institute, Bucharest, Romania \\ ${ }^{6}$ Faculty of Medicine, "Titu Maiorescu" University, Bucharest, Romania \\ "Carol Davila" University of Medicine and Pharmacy, Bucharest, Romania
}

*Corresponding author:

Florin Botea, MD

Center of General Surgery and Liver

Transplantation

Fundeni Clinical Institute

Soseaua Fundeni 258, Bucharest

Romania

E-mail: florinbotea@gmail.com

\section{Rezumat}

Rezecția hepatică echoghidată în metastazele hepatice gigante ale tumorilor gastrointestinale stromale - prezentare de caz

Prezentăm cazul unei paciente în vârstă de 37 de ani, cu istoric recent chirurgical pentru o tumoră gastrointestinală stromală cu localizare jejunală, clasificare AFIP: 6a, internată în centrul nostru pentru metastaze hepatice sincrone neoperate. Bilanțul oncologic efectuat după 12 luni, în care s-a administrat Imatinib, relevă boală stabilă. Examnarea CT decelează o metastază hepatică unică, de 14 centimetri în diametru, localizată în segmentele $\mathrm{V}$ şi VIII, ce ocupă parțial segmentele IV, IV şi VII, cu efect de masă asupra bifurcației portale, venei hepatice drepte şi venei ombilicale, care invadează vena hepatică medie. Am considerat fezabil să aplicăm conceptul de rezecție de tip $R 1$ vascular, efectuând o hepatectomie centrală limitată, non-anatomică, echoghidată, pentru a permite detaşarea tumorii de pe vena hepatică dreaptă şi de pe vena ombilicală. Astfel, am sacrificat numai pediculii portali ventrali ai segmentelor V şi VIII şi am păstrat parțial aceste segmente pentru a evita riscul insuficienței hepatice post-rezecționale. În prezent, deoarece supraviețuirea fără recidivă este de 53 de luni, susținem conceptul de rezecție hepatică echoghidată $R 1$ vascular în contextul terapiei sistemice cu inhibitori de tirozin kinază, pentru metastazele tumorilor gastrointestinale stromale. 
Cuvinte cheie: rezecție hepatică, ghidaj ecografic intraoperator, tumoră stromală gastrointestinală GIST, hepatectomie centrală

\begin{abstract}
We present the case of a 37-year-old patient with a surgical history of a gastrointestinal stromal tumor with jejunal location, AFIP classification 6a, hospitalized in our center for synchronous liver metastases. The oncological assessment performed after 12 months from surgery for primary tumor, during which Imatinib was administered, reveals stable disease. CT scan showed a single very large centrally located liver metastasis, $14 \mathrm{~cm}$ in diameter, involving segments V and VIII IV, IV and VII, compressing the main portal bifurcation, right hepatic vein, umbilical (scizural) vein and left hepatic vein, invading the middle hepatic vein. We considered it feasible to apply the concept of $\mathrm{R} 1$ vascular resection, performing a limited, non-anatomical, ultrasound-guided central hepatectomy, allowing detachment of the tumor from the right hepatic vein and from the umbilical vein. Thus, we sacrificed only the ventral portal pedicles of segments V and VIII and partially preserved these segments to avoid the risk of post-resection liver failure.Currently, the patient is disease-free after 53 months, supporting the concept of ultrasound-guided $\mathrm{R} 1$ vascular resection, in the context of systemic therapy with tyrosine kinase inhibitors for metastases of stromal gastrointestinal tumors.
\end{abstract}

Key words: liver resection, intraoperative ultrasound guidance, gastrointestinal stromal tumor GIST, central hepatectomy

\section{Introduction}

Liver metastases of gastrointestinal stromal tumors (GLM) can grow to impressive dimensions, and invade vascular structures, thus the need to perform techinically demanding ultrasound-guided liver resections. The present video shows a clinical case that benefitted from such type of resection.

\section{Case Report}

A 37-year-old woman (from a rural environment, no tertiary education), without relevant medical and surgical history, admitted on an emergency basis, for a syncopal episode associated with diffuse abdominal pain. Laboratory tests showed a hypochromic microcytic anemia $(7 \mathrm{~g} / \mathrm{dl})$. Contrast-enhanced CT-scan revealed a hemorrhagic jejunal tumor ( $84 \mathrm{~mm}$ by $70 \mathrm{~mm}$ in size) with a single large synchronous liver metastasis $(140 \mathrm{~mm}$ by 120 $\mathrm{mm}$ in size, occupying segments V and VIII and partially segments IV, IV and VII, with mass effect on the portal bifurcation, right hepatic vein and umbilical vein, all of which remain permeable, and invading the middle hepatic vein. A jejunal segmental enterectomy with end-to-end anastomosis (alongside the resection of invaded the mesentery and epiploonum) was performed in an emergency setting, for the primary jejunal loop tumor. We considered d'emblee resection prohibited: due to the emergency setting, the technical complexity of the prospective liver resection and the absence of any complication related to the liver metastases. Immunohistochemistry showed a GIST, prognostic group $6 \mathrm{a}(>5$ mitoses/50 HPF), CD117, CD34, SMA, S100, DOG1 positive; and a Ki67 index of $20 \%$. After debate, our institute's multidisciplinary team decided to initiate tyrosine kinase inhibitor (TKI) therapy with Imatinib $400 \mathrm{mg} /$ day, considered nowadays a standard pre-hepatectomy approach (1). The 12-month oncological follow-up showed stable disease according to the RECIST criteria (2). 
Preoperative liver volumetry revealed: total liver volume: $2543 \mathrm{cmc}$; tumor volume: 1010 cmc; volume of segments VI and VII, and tumor-free portion of segments V and VIII: 414 cmc; volume of segments II and III: $158 \mathrm{cmc}$. The resection was carried by the means of a right thoraco-phrenolaparotomy (a J-shaped incision prolonged in the 9th right intercostal space), we adopted a parenchymal sparing R1 vascular resection approach, by performing a non-anatomical limited central hepatectomy using ultrasound guidance, by detaching the tumor off the right hepatic veins, umbilical (scisural) vein, main portal pedicles and the right anterior portal pedicle. In this way, we sacrificed the ventral portion of segment $\mathrm{V}$ and VIII while preserving the portal pedicles dorsal branches for these segments. The transection was performed using the crush clamping technique under ultrasound guidance. Vascular control by intermittent Pringle maneuver (9 intervals of 15 minutes with breaks of 5 minutes, except every 4th break which consisted in 10 minutes) was deployed.

\section{Results}

The operative time was $555 \mathrm{~min}$, blood losses counted for $2500 \mathrm{ml}$ and the number of transfused blood units was 3 MER. There were no intraoperative incidents. The postoperative course was marked by ascites remitted spontaneously on the $18^{\text {th }}$ postoperative day (POD); the patient was discharged on $23^{\text {rd }}$ POD. Histology and immunohistochemistry showed GLM with positive CD 117, DOG 1, and a Ki-67 Index of $20 \%$, with mitotic count $>$ $5 / 50$ HPF. Systemic therapy with Imatinib 400 $\mathrm{mg} /$ day, was resumed 1 month after liver resection, and is currently under administration. Currently, the patient is disease-free at 53 months after the liver resection.

\section{Discussion}

Tyrosine kinase inhibitor (TKI) therapy is currently considered a standard prehepatectomy approach (1). Although the optimal timing of GLM resection continues to be debated, waiting 3 to 9 months after the initiation of TKI therapy is recommended, since this time frame usually represents the period of greatest radiological response (3). There are multiple studies suggesting that operating during periods of responsive disease or stable disease correlates to improved outcomes compared to progressive disease $(4,5)$. To successfully intervene at the time of greatest response, the surgeon must closely follow the radiological response (1). A central anatomic hepatectomy would not have been feasible in this case due to insufficient remnant liver volume. $\mathrm{R} 0$ resection would have not been feasible in this case, even considering vascular reconstruction, because the tumor involved all major vessels and portal pedicles (all hepatic veins and both main portal pedicles). Liver transplant was also considered unfeasible, due to high recurrence risk suggested by the high primary tumor prognostic group $(6 a ;>5$ mitoses/50 HPF; Ki67 index of 20\%), high liver tumor burden. Moreover, liver transplantation for metastatic GIST has been minimally employed and has limited utility (6). Therefore, we accepted $\mathrm{R} 1$ vascular resection in this case as the only strategy available for surgical treatment. Although, literature states the need of R0 resection (4), and NCCN guidelines do not specify the need for extensive margins (7), the acceptance of the R1 vascular resection concept in case of GLM may be criticized, due to the current lack of investigation. However, the long-term oncological result in our case supports the feasibility of $\mathrm{R} 1$ vascular resection strategy for GIST liver metastases, as already proven in case of colorectal liver metastases (8), hepatocellular carcinoma (9), but not for intrahepatic cholangiocarcinoma (10).

\section{Conclusion}

We consider ultrasound-guided liver resection in the context of TKI systemic therapy, the most appropriate way in approaching the technically demanding, large and vascular invasive GLM, in order to obtain negative 
resection margins, paying special attention to the response of TKI prior to liver resection, thus establishing the proper timing of surgery. Taking into consideration the high diseasefree survival in this case, we recommend $\mathrm{R} 1$ vascular resection in case of GLM otherwise unresectable.

\section{Acknowledgements}

This material is part of a larger retrospective study of a $\mathrm{PhD}$ thesis, currently under development by Kraft Alin-Alexandru MD, Ph.D student, currently pending full publication, entitled "The surgical treatment of liver metastases arising from non-colorectal neoplasia", developed at "Titu Maiorescu" Doctoral School of Medicine, Bucharest, Romania, with Irinel Popescu, University Professor, $\mathrm{PhD}$, as thesis coordinator.

\section{References}

1. Morris AD, Maithel SK, David A. Kooby. Management of Liver Metastases of Gastrointestinal Stromal Tumors. [book auth.] John T. Mullen Charles R.
Scoggins. Chandrajit P. Raut. Gastrointestinal Stromal Tumors Bench to Bedside. s.I.: Springer International Publishing Switzerland, 2017.

2. Eisenhauer EA, Therasse P, Bogaerts J, Schwartz LH, Sargent D, Ford R, et al. New response evaluation criteria in solid tumours: revised RECIST guideline (version 1.1). Eur J Cancer. 2009;45(2):228-47.

3. Xia L, Zhang MM, Ji L, Li X, Wu XT. Resection combined with imatinib therapy for liver metastases of gastrointestinal stromal tumors. Surg Today. 2010;40(10):936-42.

4. Cananzi FC, Belgaumkar AP, Lorenzi B, Mudan S. Liver surgery in the multidisciplinary management of gastrointestinal stromal tumour. ANZ $J$ Surg. 2014 Dec;84(12):E1-8

5. Gronchi A, Fiore M, Miselli F, Lagonigro MS, Coco P, Messina A, et al. Surgery of residual disease following molecular-targeted therapy with imatinib mesylate in advanced/metastatic GIST. Ann Surg. 2007;245(3): 341-6.

6. Serralta AS, Sanjuan FR, Moya AH, Orbis FC, López-Andújar R, Pareja El, et al. Combined liver transplantation plus imatinib for unresectable metastases of gastrointestinal stromal tumours. Eur J Gastroenterol Hepatol. 2004; 16(11):1237-9.

7. Demetri GD, Benjamin RS, Blanke CD, Blay JY, Casali P, Choi H, et al. NCCN Task Force report: management of patients with gastrointestinal stromal tumor (GIST)--update of the NCCN clinical practice guidelines. J Natl Compr Canc Netw. 2007;5 Suppl 2:S1-29; quiz S30.

8. Viganò L, Costa G, Cimino MM, Procopio F, Donadon M, Del Fabbro D, et al. R1 Resection for Colorectal Liver Metastases: a Survey Questioning Surgeons about Its Incidence, Clinical Impact, and Management. J Gastrointest Surg. 2018;22(10):1752-1763.

9. Donadon M, Terrone A, Procopio F, Cimino M, Palmisano A, Viganò L, et al. Is R1 vascular hepatectomy for hepatocellular carcinoma oncologically adequate? Analysis of 327 consecutive patients. Surgery. 2019;165(5): 897-904.

10. Torzilli G, Viganò L, Fontana A, Procopio F, Terrone A, Cimino MM, et al. Oncological outcome of R1 vascular margin for mass-forming cholangiocarcinoma. A single center observational cohort analysis. HPB (Oxford). 2020;22(4):570-577. 